九州大学学術情報リポジトリ

Kyushu University Institutional Repository

\title{
Case Study on the Changes in the Physical Environment in Forest Healing Spaces
}

\section{Kim, Geonwoo}

Department of Environment and Forest Resources, College of Agriculture \& Life Sciences, Chungnam National University

Park, Bum-Jin

Department of Environment and Forest Resources, College of Agriculture \& Life Sciences, Chungnam National University

Yeon, Poung-Sik

Department of Forest Science, College of Agriculture, Life \& Environment Sciences, Chungbuk National University

\section{Lee, Sanggoo}

Department of Environment and Forest Resources, College of Agriculture \& Life Sciences, Chungnam National University

他

https://doi.org/10.5109/1686502

出版情報：九州大学大学院農学研究院紀要. 61 (2)，pp.375-381，2016-09-01. Faculty of Agriculture, Kyushu University

バージョン：

権利関係: 


\title{
Case Study on the Changes in the Physical Environment in Forest Healing Spaces
}

\author{
Geonwoo KIM1, Bum-Jin PARK' ${ }^{1}$, Poung-Sik YEON ${ }^{2 *}$, Sanggoo LEE ${ }^{1}$, \\ Dawou JOUNG ${ }^{1}$, Choonghee PARK ${ }^{1}$ and Shinya KOGA \\ Laboratory of Forest Resources Management, Division of Forest Environmental Sciences, \\ Department of Agro-environmental Sciences, Faculty of Agriculture, \\ Kyushu University, Sasaguri, Fukuoka 811-2415, Japan \\ (Received April 27, 2016 and accepted May 10, 2016)
}

\begin{abstract}
This study was conducted to investigate changes in the physical environment in forest healing spaces by examining each of two tree species in a space within the Kasuya Research Forest, Kyushu University. At the study site, culmination and sunset showed high TNVOCs, low concentrations of particulate matter, and low PPD. Of the NVOCs, camphor was detected with the highest concentrations, $0.359 \mathrm{ng} / \mathrm{m}^{3}$ and $0.142 \mathrm{ng} / \mathrm{m}^{3}$, in C. camphora and $M$. thunbergii, respectively. Coniferous trees are generally used when creating an environment for healing purposes, as they are known to emit a large amount of NVOCs. However, according to our results, deciduous trees also emit NVOCs of sufficient concentrations. Therefore, if forest healing spaces are created with the appropriate components, it can have effective results.
\end{abstract}

Key words: PM2.5, PMV, PPD, Terpene, Theraphy

\section{INTRODUCTION}

With the increasing number of senior citizens and patients with chronic diseases and lifestyle diseases, there is an increasing need for spaces in nature that accommodate physical and mental stability. While treatment helps a patient recover from an illness using medical means, healing is a way to approach a patient's health using social, cultural, and environmental supports. Therefore, healing not only encompasses treating illnesses but also extends to preventing diseases and improving health. Interest in health, well-being, and alternative medicine is increasing, and these topics are receiving increasing levels of attention (Smith et al., 2013; Wrench et al., 2013). People pursue health through activities in nature to destress from work and sensory overload within artificial, urban environments (Ulrich et al., 1991) and to recover their own physical balance and harmony. Additionally, activities based in natural environments decrease death rates (Richardson et al., 2013) and allow the pursuit of benefits related to health, such as mental stability, comfort, and recovery of attention (Adams et al., 1997; Korpela et al., 2014). Because of a change in mindset that has shifted health interests from treating diseases to improving health, preventing disease, and improving of quality of life, a demand to use urban and suburban forests as healing or curative spaces is increasing (Park et al., 2014; Kim et al., 2015; Joung et al., 2015). With the realization that healing environments such as forests, which are a representative natural healing environment, need to be improved, there is an increasing

1 Department of Environment and Forest Resources, College of Agriculture \& Life Sciences, Chungnam National University, 99 Daehak-ro, Yuseong-gu, Daejeon 305-764, Republic of Korea

2 Department of Forest Science, College of Agriculture, Life \& Environment Sciences, Chungbuk National University, Chungdae-ro1, Seowon-Gu, Cheongju, Chungbuk 28644, Republic of Korea

* Corresponding author (E-mail: imoscow@hanmail.net) need to conduct the corresponding fundamental research. Physiological and psychological studies on healing environments have increased; however, research that is directly related to the factors affecting in healing environments (e.g., NVOCs, temperature, humidity, wind velocity, dew point, globe temperature, air current, wet-bulb globe temperature, and photosynthesis) is inadequate. Therefore, to conduct a scientific analysis of such factors, we first aim to evaluate healing environments by analyzing the NVOCs in these environments. Second, by understanding the relationships between particulate matter, which is an emerging global issue, and physical environments, we aim to discuss the uses of healing environments.

\section{MATERIALS AND METHODS}

\section{Study site}

Kasuya Research Forest, Kyushu University

The study site is an urban forest located in the Kasuya Research Forest, Kyushu University (333' $15.2^{\prime \prime}$ N $130^{\circ} 30^{\prime} 51.1^{\prime \prime} \mathrm{E}$ ) in Japan. The site is easily accessible to citizens, well preserved, and has an excellent landscape. The forest has an area of approximately 500 ha, comprises tree species dominated by Japanese cedar and cypress, and is a target area for active studies on forest hydraulics and forest dynamics. This study focuses on measurements of Cinnamomum camphora Sieb. and Machilus thunbergii Sieb. et Zucc.; C. camphora and $M$. thunbergii are known to have various therapeutic effects.

\section{Measurement factors} NVOCs

Volatile organic compounds (VOCs) are either liquid or gaseous organic compounds that have boiling points below $100^{\circ} \mathrm{C}$ and are easily evaporated into the atmosphere. This study concentrated on the methods for analyzing natural volatile organic compounds (NVOCs). A 
majority of NVOCs emitted in forests are generated by trees. Medical studies researching the effects of NVOCs and how to cope with the diseases they cause have been published internationally (Yatagai et al., 1995; Trapp et al., 2001; Tani et al., 2002; Wang et al., 2006; Tani and Kawawata, 2008; Yang et al., 2011; Wang et al., 2012). Terpene compounds, which are a type of NVOC emitted by trees, are produced from multiple base units of isoprene, which contains five carbon and eight hydrogen atoms. Terpenoids, a common and large NVOC group, comprise hemiterpenes, monoterpenes, and sesquiterpenes. Emission inventories show that isoprene and monoterpenes are the most prominent compounds. These compounds are usually strong smelling, rarely water soluble, and found in plants as well as in animals and microorganisms (Kesselmeier and Staudt, 1999). In this study, 20 species of monoterpenes (99\%, Sigma-Aldrich, USA), including $\alpha$-pinene, $\beta$-pinene, and camphene, were selected for analysis.

\section{Predicted mean vote and predicted percentage of thermally dissatisfied people}

Thermal balance is obtained when the internal heat production of a body equals its loss of heat to the environment. In a moderate environment, the human thermoregulatory system will automatically attempt to modify skin temperature and sweat secretion to maintain thermal balance. PMV is an index that predicts the mean value of the thermal votes of a large group of people exposed to the same environment on a 7 -point thermal sensation scale based on the heat balance of the human body (Table 1). However, individual votes are scattered around this mean value; therefore, it is useful to be able to predict the number of people who may feel uncomfortably warm or cool at the mean value. PPD is an index that establishes a quantitative prediction of the percentage of thermally dissatisfied people who feel too cool or too warm. In this study, thermally dissatisfied people are considered as those who vote hot, warm, cool, or cold on the 7-point thermal sensation scale (ISO 7730, 2005).

\section{Particulate matter}

Particulate matter (PM) affects more people than any other pollutant. The major components of PM are sulfate, nitrates, ammonia, sodium chloride, black carbon, mineral dust, and water. PM consists of a complex mixture of solid and liquid particles of organic and inorganic substances suspended in the air (Table 2). The most healthdamaging particles are those with a diameter of 10 microns or less ( $\leq$ PM10), which can penetrate and lodge deep inside the lungs (WHO, 2005; WHO, 2014). Longterm exposure to particles contributes to risks of developing cardiovascular and respiratory diseases, as well as lung cancer (Abbey et al., 1999; Pope III et al., 2002; Katanoda et al., 2011; IARC, 2015). Fine particles, those with a diameter equal to or less than 2.5 microns (PM2.5), can be emitted directly into the atmosphere, such as black carbon emissions from a diesel engine or smoke from a fire, or they can form from chemical reactions of precursor gases, including sulfur dioxide, nitrogen dioxide, certain VOCs, and ammonia. Sources of PM2.5 (or the precursor gases that contribute to PM2.5 formation) include power plants, gasoline and diesel engines, wood combustion, high-temperature industrial processes such as smelters and steel mills, and forest fires (EPA, 2015).

\section{Measurement methods}

NVOCs

The adsorption tube method was used to collect samples. Tubes (Makers, USA) filled with Tenax TA and Carbotrap 2B were used for adsorption. The sample capture device was a mini pump (MP- $230 \mathrm{KN}$, SIBATA, Japan), and the calibration was proceeded by a calculation of the adsorption error prior to the use of the flow meter. A total NVOC volume of $15 \mathrm{~L}$ was collected at a flow rate of $150 \mathrm{~mL} / \mathrm{min}$. The sampling equipment was installed on a tripod, $1.5 \mathrm{~m}$ from the ground, and the average value was calculated through duplicate sampling at every location. Disposable polyethylene gloves and antibacterial masks were used to prevent artificial errors when in contact with the tube during installation. After sampling, the sample tubes were maintained at tempera-

Table 1. Seven-point thermal sensation scale

\begin{tabular}{cccccccc}
\hline-3 & -2 & -1 & 0 & +1 & +2 & +3 & +2 \\
\hline Cold & Cool & Slightly cool & Neutral & Slightly warm & Warm & Hot \\
\hline
\end{tabular}

Table 2. Guideline values of set limits for PM in the air

\begin{tabular}{lccc}
\hline & Guideline & PM $10\left(\mu \mathrm{g} / \mathrm{m}^{3}\right)$ & PM 2.5 $\left(\mu \mathrm{g} / \mathrm{m}^{3}\right)$ \\
\hline \multirow{2}{*}{ WHO } & Yearly average & 20 & 10 \\
& Daily average & 50 & 25 \\
\hline \multirow{2}{*}{ Japan } & Yearly average & None & 15 \\
& Daily average & 100 or 200 & 35 \\
\hline \multirow{2}{*}{ Korea } & Yearly average & 50 & 25 \\
& Daily average & 100 & 50 \\
\hline
\end{tabular}


Table 3. GC/MS operating parameters for NVOCs

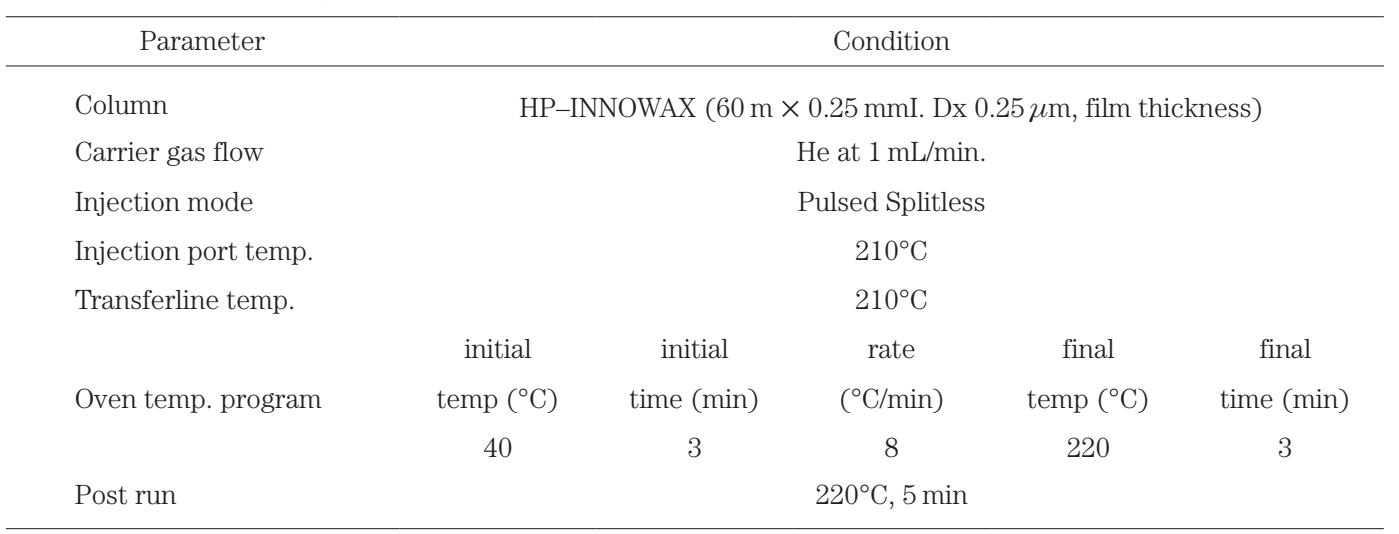

tures below $4^{\circ} \mathrm{C}$ and analyzed within $48 \mathrm{~h}$. The samples were subjected to qualitative and quantitative analyses using a gas chromatography (GC)/mass spectrometer (7890N-5975, Agilent, USA) with a thermal desorption system (GC/MSD, Gerstel TDS, Gerstel, Germany). The substances adsorbed by the adsorption tube were concentrated in a low-temperature cryofocusing device, which intakes high-purity helium gas at a velocity of $1 \mathrm{~mL} / \mathrm{min}$ from a thermal desorption device. The device desorbed the gas for $3 \mathrm{~min}$ at $210^{\circ} \mathrm{C}$ and then maintained its temperature at $-30^{\circ} \mathrm{C}$. The substances were then subjected to thermal desorption for $3 \mathrm{~min}$ at $220^{\circ} \mathrm{C}$, infused into a GC spectrometer, and detected using an MSD (Table 3).

\section{Vegetation survey}

A $20 \mathrm{~m} \times 20 \mathrm{~m}$ quadrant was established at the NVOC measurement site, and plant species were divided into a tree layer, a subtree layer, and a shrub layer to conduct a plant sociological survey. Records of the average tree height and crown projection charts of the tree layer were prepared. A log-wood survey of the tree species measuring $\geq 2 \mathrm{~cm}$ in diameter at breast height (DBH) in the study site was performed. The direction and slope of the site were measured in terms of the locational environment. A setup was designed to ensure that a portable multifunction meter (Poly MI 6401, METREL, Slovenia) recorded the physical features of the site environment (temperature, humidity, wind velocity, dew point, globe temperature, air current, and wet-bulb globe temperature) at intervals of $1 \mathrm{~min}$. The meter was installed at a height of $1.5 \mathrm{~m}$ in equilibrium on a tripod approximately $1 \mathrm{~m}$ from a mini pump, and digitalized measurement results were saved and then converted for analysis. The results were analyzed using the Sensor Link PRO program (METREL, Slovenia). The data saved 5 min before and after each measurement were excluded from the analysis to minimize measurement errors.

\section{Particulate matter}

Methods used to measure particulate matter in the air include the high and low volume air sampler method, which measures the mass directly, and the $\beta$-ray, light scattering, and light transmission methods, which are indirect methods that utilize the particle's physical characteristics. In this study, measurements were conducted using the light scattering method. This method measures the concentration of particulate matter using the principle that the amount of light scattered when the light is transmitted through the particulate matter is proportional to its mass.

The most important advantages of the light scattering method are its mobility, low cost, ease of use, and its ability to measure particle concentrations over short time intervals (Tittarelli et al., 2008). The meter was installed at a height of $1.5 \mathrm{~m}$ in equilibrium on a tripod approximately $1 \mathrm{~m}$ from a mini pump, and digitalized measurement results were saved and then converted for analysis. A setup was designed to ensure that a portable real-time monitoring meter (LD-5, SIBATA, Japan) recorded the properties of the site's particulate matter at intervals of 5 min.

\section{RESULTS}

\section{Variation of NVOCs}

A total of 18 substances were detected from the analysis of 20 NVOCs, including $\alpha$-pinene, and camphor had the highest concentration among the detected. Most substances had similar distributions of their concentration characteristics (Table 4). The order of concentration was camphor $>$ cedrol $>\alpha$-pinene. C. camphora emitted camphor $\left(0.359 \mathrm{ng} / \mathrm{m}^{3}\right)$, cedrol $\left(0.115 \mathrm{ng} / \mathrm{m}^{3}\right)$, $\alpha$-pinene $\left(0.083 \mathrm{ng} / \mathrm{m}^{3}\right)$, camphene $\left(0.041 \mathrm{ng} / \mathrm{m}^{3}\right)$, and limonene $\left(0.038 \mathrm{ng} / \mathrm{m}^{3}\right)$. M. thunbergii emitted camphor $\left(0.142 \mathrm{ng} / \mathrm{m}^{3}\right)$, cedrol $\left(0.051 \mathrm{ng} / \mathrm{m}^{3}\right), \alpha$-pinene (0.031 ng/ $\left.\mathrm{m}^{3}\right)$, limonene $\left(0.031 \mathrm{ng} / \mathrm{m}^{3}\right)$, and myrcene $\left(0.029 \mathrm{ng} / \mathrm{m}^{3}\right)$. The TNVOCs revised by flow rates in C. camphora and $M$. thunbergii were $0.789 \mathrm{ng} / \mathrm{m}^{3}$ and $0.386 \mathrm{ng} / \mathrm{m}^{3}$, respectively. C. camphora emitted the highest concentration of NVOCs. NVOCs detected from C. camphora increased in concentration as time progressed from sunrise to sunset, and NVOCs detected from $M$. thunbergii had their highest concentration during culmination (Figure 1).

\section{Results of the vegetation survey}

C. camphora community

The $C$. camphora community had a $\mathrm{DBH} \geq 172.8 \mathrm{~cm}$ 
Table 4. Concentration $\left(\mathrm{ng} / \mathrm{m}^{3}\right)$ of NVOCs at the study site

\begin{tabular}{lcc}
\hline & $\begin{array}{c}\text { Cinnamomum } \\
\text { camphora }\end{array}$ & $\begin{array}{c}\text { Machilus } \\
\text { thunbergii }\end{array}$ \\
\hline$\alpha$-pinene & 0.083 & 0.031 \\
Camphene & 0.041 & 0.014 \\
$\beta$-pinene & 0.018 & 0.010 \\
Sabinene & 0.010 & 0.007 \\
carene & 0.007 & 0.001 \\
$\alpha$-phella0rene & 0.003 & 0.003 \\
Myrcene & 0.037 & 0.029 \\
$\alpha$-terpinene & 0.013 & 0.006 \\
Limonene & 0.038 & 0.031 \\
Eucalyptol(cineole) & 0.016 & 0.018 \\
$\gamma$-terpinene & 0.005 & 0.004 \\
Cymene & 0.021 & 0.017 \\
Camphor & 0.359 & 0.142 \\
Linalool & 0.004 & 0.005 \\
Bornyl acetate & 0.011 & 0.010 \\
$\alpha$-humulene & 0.002 & 0.001 \\
Terpineol & 0.006 & 0.006 \\
Cedrol & 0.115 & 0.051 \\
\hline
\end{tabular}

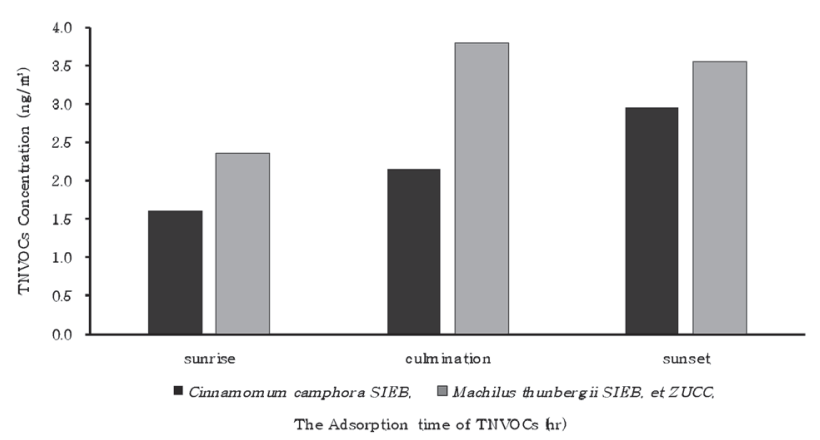

Fig. 1. Variation of TNVOCs at the study site.

and a slope of $3^{\circ}$. The tree layer had an average tree height of $20.1 \mathrm{~m}$ and contained two tree species (Figure 2 ). The average temperature, humidity, wind velocity, and black globe temperature of the site were $22.35^{\circ} \mathrm{C}$, $52.40 \%, 0.80 \mathrm{~m} / \mathrm{s}$, and $23.20^{\circ} \mathrm{C}$, respectively. The analysis of the thermal comfort factor of $C$. camphora resulted in a PMV and PPD of -0.61 and $24.86 \%$, respectively. The time period between 10 am and 12 pm was relatively pleasant and therefore was considered to be a period of low thermal discomfort (Figures 3 and 4).

\section{M. thunbergii community}

The $M$. thunbergii community had a DBH $\geq 171 \mathrm{~cm}$ and a relatively steep slope of $20^{\circ}$. The tree layer had an average tree height of $18.5 \mathrm{~m}$ (Figure 5). The average temperature, humidity, wind velocity, and black globe temperature of the site were $21.53^{\circ} \mathrm{C}, 53.49 \%, 0.44 \mathrm{~m} / \mathrm{s}$, and $22.25^{\circ} \mathrm{C}$, respectively. When the thermal comfort fac-

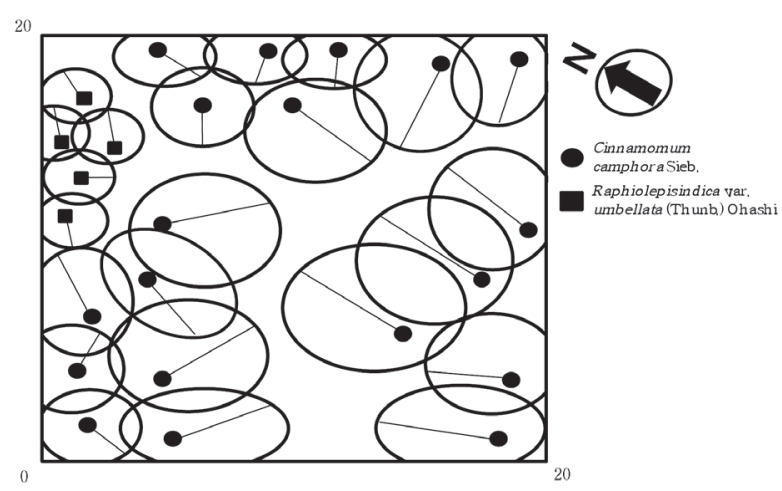

Fig. 2. Crown projection in the Cinnamomum camphora community $(20 \mathrm{~m} \times 20 \mathrm{~m})$.

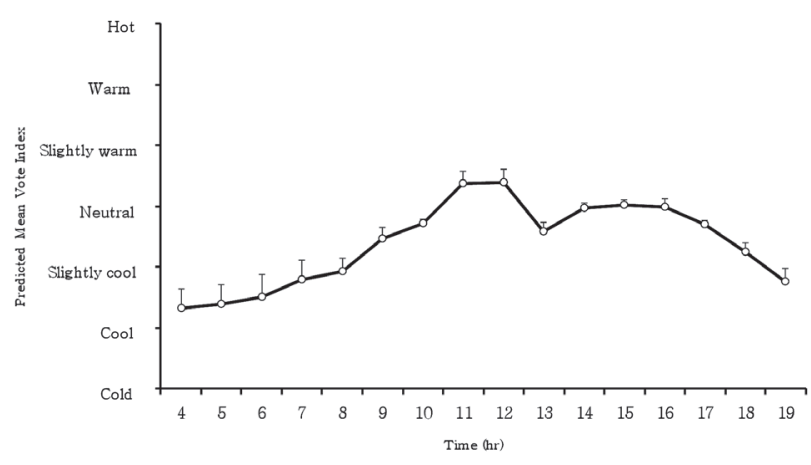

Fig. 3. PMV result for the Cinnamomum camphora site.

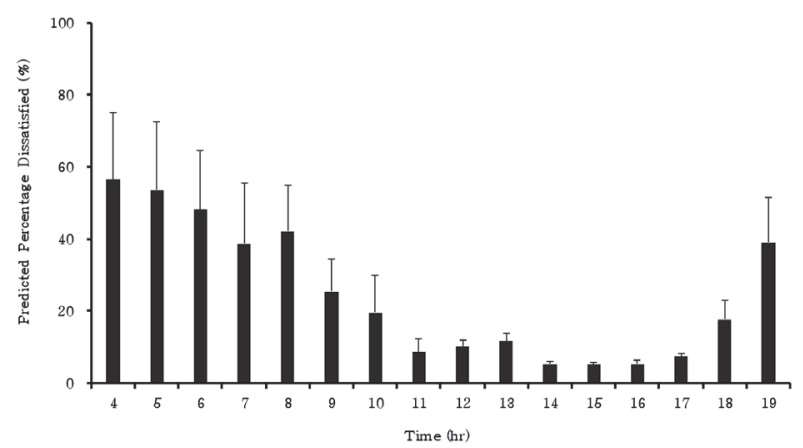

Fig. 4. PPD result for the Cinnamomum camphora site.

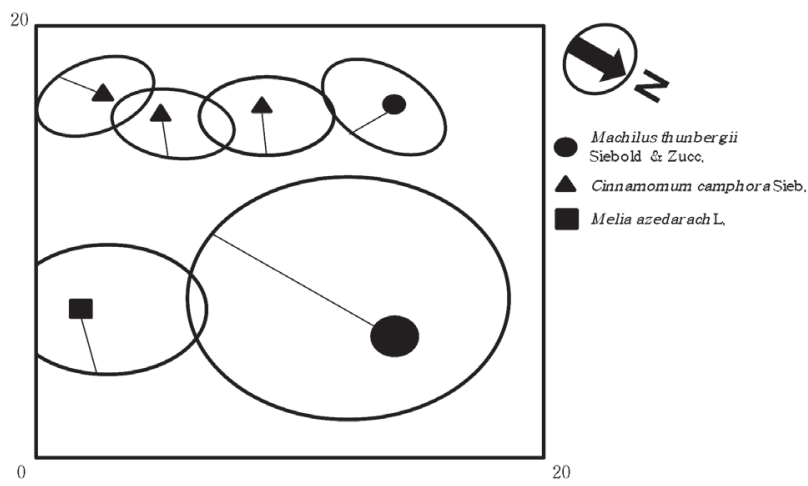

Fig. 5. Crown projection in the Machilus thunbergii community $(20 \mathrm{~m} \times 20 \mathrm{~m})$ 


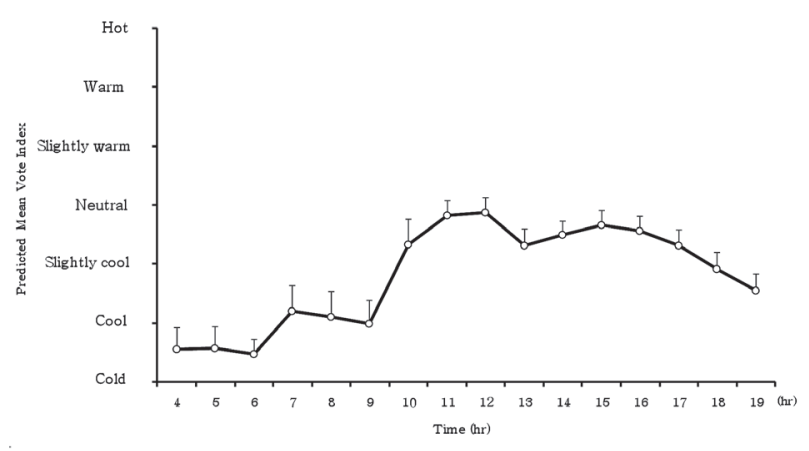

Fig. 6. PMV result for the Machilus thunbergii site.

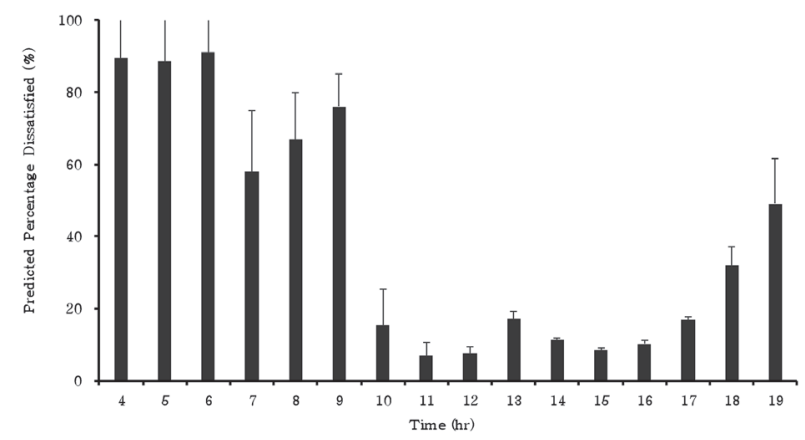

Fig. 7. PPD result for the Machilus thunbergii site.

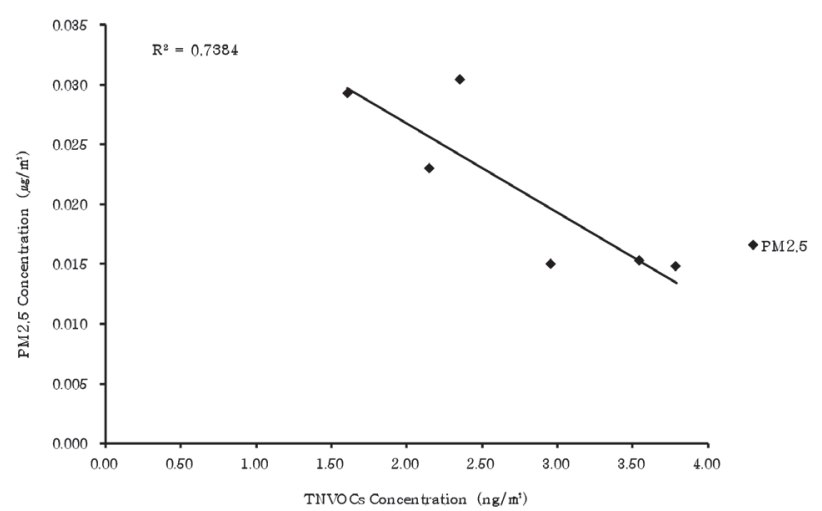

Fig. 8. Relationship between TNVOCs and PM2.5 in the study site.

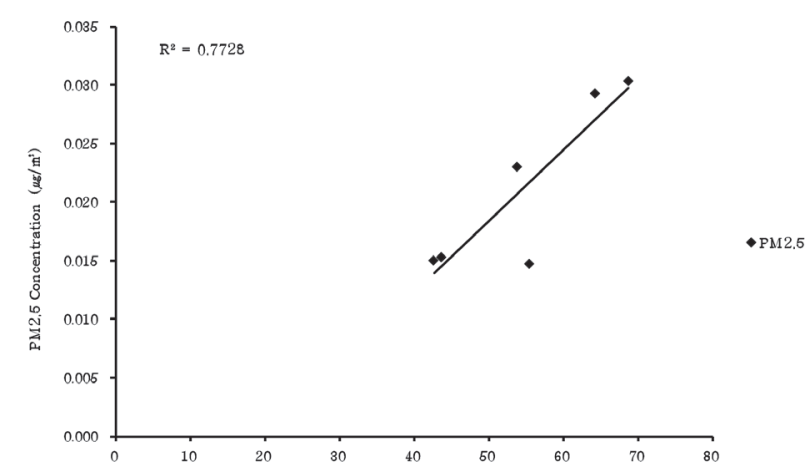

Fig. 9. Relationship between humidity and PM2.5 in the study site. tor of $M$. thunbergii was analyzed, PMV and PPD were found to be -1.24 and $33.48 \%$, respectively, and the community was confirmed to be relatively fresh from 11 am to 4 pm (Figures 6 and 7).

\section{Correlation between the particulate matter and the physical environment}

To understand the correlation between the particulate matter and the forest environments within the study site, PM2.5 was measured every $5 \mathrm{~min}$, and its average was calculated every hour. A correlation analysis was conducted between PM2.5, the measured physical environment, and TNVOCs for the same area and same time period (sunrise, culmination, and sunset). To maintain the accuracy of the measured values, data taken from the first 5 min of each measurement were excluded. As a result, a negative linear relationship was confirmed between TNVOCs and PM2.5, where the weight of PM2.5 decreased with increasing concentration of TNVOCs (Figure 8). A positive linear relationship was confirmed with the humidity, showing that the weight of PM2.5 increased with increasing humidity (Figure 9).

\section{DISCUSSION}

This study was conducted to illustrate the changes in and correlations between TNVOCs, the physical environment (temperature, humidity, wind velocity, dew point, globe temperature, air current, and wet-bulb globe temperature), the thermal environment (PMV and PPD), and particulate matter (PM2.5) in forest healing spaces for the trees at Kyushu University in Japan. Deciduous trees, which have not previously been a subject of research, were selected instead of coniferous trees. $C$. camphora and $M$. thunbergii, which are well known for their high contents of medicinal ingredients and their high utility for folk remedies, were chosen.

Based on the NVOC concentrations, it was confirmed that both tree species have similar component ratios. Analysis of the NVOCs emitted at the study site showed that 18 types of substances were detected. TNVOC concentrations emitted by $C$. camphora and $M$. thunbergii were $0.789 \mathrm{ng} / \mathrm{m}^{3}$ and $0.386 \mathrm{ng} / \mathrm{m}^{3}$, respectively. According to previous studies, NVOC emission in each season is related to environmental effects, growth amount, and leaf age. Therefore, although the observed concentrations were relatively lower than those of Chamaecyparis obtusa $\left(1.310 \mathrm{ng} / \mathrm{m}^{3}\right)$ and Cryptomeria japonica $\left(1.591 \mathrm{ng} / \mathrm{m}^{3}\right)$, which are known to have high emissions of NVOCs, considering that it was the spring season, it is believed that they are adequate for healing purposes. Further, because their bark and leaves are used for medicinal purposes and are known to be medically effective, it is necessary to analyze the ingredients produced from the bark and leaves in dry conditions.

The analyses of PMV and PPD verified that PMVs were close to neutrality (a relatively pleasant range) after culmination in both study sites from 10 am until sunset. The probability that a person would feel dissatisfied with the thermal comfort (PPD) after culmination was 28.5 
( \pm 21.7$) \%$, which is relatively low. Therefore, forest healing spaces are in a pleasant range, indicating that thermal comfort is an important factor in forest healing environments.

The analysis of the correlation between the physical environment (temperature, humidity, wind velocity, and intensity of illumination) and particulate matter (PM2.5) indicates that the particulate matter weight decreased with increasing concentrations of TNVOCs. On the other hand, particulate matter weight increased with increasing humidity. There was a high correlation between TNVOCs, humidity, and particulate matter. Nonetheless, it is necessary to complement this study with a number of experiments and to consider differences between tree species and seasons.

For the sites used in this study, culmination and sunset showed high TNVOCs, low concentrations of particulate matter, and low PPD; therefore, we expect that performing a regular activity such as participating in a program, taking a walk, or meditating during culmination would result in high mental and physical stability. Camphor had the highest detection concentration of the NVOCs emitted by both $C$. camphora and $M$. thunbergii and is known to be effective as an anti-carcinogenic substance and for coughs (Sharma et al., 2011; Ho and Su, 2012; Hamidpour et al., 2013). Cedrol, which is also emitted with a relatively high concentration, is known to be effective for decreasing blood pressure (Kawakami et al., 2004). Cedrol does not volatilize from most coniferous trees or is detected in very small concentrations. When creating an environment for healing purposes, coniferous trees are generally used, as they are known to emit large amounts of NVOCs. However, this study shows that deciduous trees also emit NVOCs of sufficient concentrations; therefore, if a healing environment is created with the proper components, it can have effective results. It is necessary to research the influences of the healing environments presented in this study on a human body. The results of this study could serve as a novel aid with regards to healing perspectives when planning spaces within forests.

\section{ACKNOWLEDGMENTS}

This study was conducted in collaboration with the Kyushu University Forest in Japan. The authors thank Professor Kyoichi OTSUKI for valuable discussions and extensive help with the field research. This study was performed with the support of the Forest Science \& Technology Projects (Project No. S211214L010110) provided by the Korea Forest Service.

\section{REFERENCES}

Abbey, D. E., N. Nishino, W. F. McDonnell, R .J. Burchette, S. F. Knutsen, W. Lawrence Beeson and J. X. Yang 1999. Longterm inhalable particles and other air pollutants related to mortality in nonsmokers. Am. J. Respir. Crit. Care Med., $\mathbf{1 5 9}(2): 373-382$

Adams, T., J. Bezner and M. Steinhardt 1997 The conceptualization and measurement of perceived wellness: Integrating bal- ance across and within dimensions. Am. J. Health Promot., 11(3): 208-218

EPA 2015 Fine Particle Matter National Ambient Air Quality Standards: Proposed State Implementation Plan Requirements. 80(55): 15340-15474

Hamidpour, R., S. Hamidpour, M. Hamidpour and M. Shahlari 2013 Camphor (Cinnamomum camphora), a traditional remedy with the history of treating several diseases. IJCRI., 4(2): 86-89

IARC 2015 Outdoor Air Pollution. IARC Monogr Eval Carcinog Risks Hum., 109: 1-454

ISO 2005 Ergonomics of the thermal envitonment-Analytical determination and interpretation of thermal comfort using calculation of the PMV and PPD indices and local thermal comfort criteria. International Standard ISO7730., 1-10

Ho, C. L and Y. C. Su 2012 Compostion, Antioxidant and Antimicrobial Activities of Leaf Essential Oil of Machius japonica from Taiwan. NPC., 7(1): 109-112

Joung, D., G. Kim, Y. Choi, H. Lim, S. Park, J. M. Woo and B. J. Park 2015 The prefrontal cortex activity and psychological effects of viewing forest landscapes in autumn season. Int. J. Environ., 12: 7235-7243

Kawakami, K., M. Kawamoto, M. Nomura, H. Otani, T. Nabiki and T. Gonda 2004 Effects of phytoncides on blood pressure under restraint stress in SHRSP. Clin. Exp. Pharmacol. Physiol., 31: S27-28

Katanoda, K, T. Sobue, H. Satoh, K. Tajima, T. Suzuki, H. Nakatsuka, T. Takezaki, T. Nakayama, H. Nitta, K. Tanabe and S. Tominaga 2011 An association between long-term exposure to ambient air pollution and mortality from lung cancer and respiratory diseases in Japan. J. Epidemiol., 21: 132-143

Kesselmeier, J. and M. Staudt 1999 Biogenic volatile organic compounds (VOC): an overview on emission, physiology and ecology. J. Atmos. Chem., 33: 23-88

Kim, G., B. J. Park, D. Joung, D. G. Yeom and S. Koga 2015 Healing environments of major tree species in Kyushu University Forests: a case study. J. Fac. Agr. Kyushu Univ., 60(2): 477-483

Korpela, K., K. Borodulin, M. Neuvonen, O. Paronen and L. Tyrväinen 2014 Analyzing the mediators between naturebased outdoor recreation and emotional well-being. J. Environ. Psychol., 37: 1-7

Park, B. J., J. N. Ka, M. Lee, S. A. Kim, M. W. Park, Y. Choi, D. Joung, C. W. Kwon, D. G. Yeom, S. Park, J. Lee and G. Kim 2014 Physiological effects of walking and viewing on human at a urban arboretums. J. Korean For. Soc., 103(4): 664-669

Pope III, C. A., R. T. Burnett, M. J. Thun, E. E. Calle, D. Krewski, K Ito and G.D. Thurston 2002 Lung cancer, cardiopulmonary mortality, and long-term exposure to fine particulate air pollution. JAMA., 287(9): 1132-1141

Richardson, E. A., J. Pearce, R. Mitchell, and S. Kingham 2013 Role of physical activity in the relationship between urban greenspace and health. Public Health., 127(4): 318-324

Sharma, H., L. Parihar and P. Parihar 2011 Review on cancer and anticancerous properties of some medicinal plants. J. Med. Plant. Res., 5(10): 1818-1835

Smith, L. M., J. L. Case, H. M. Smith, L. C. Harwell and J. K. Summers 2013 Relating ecosystem services to domains of human well-being: Foundation for a US index. Ecol. Indic., 28: 79-90

Tani, A. and J. Kawawata 2008 Isoprene emission from the major native Quercus spp. in Japan. Atmos. Environ., 42: 4540-4550

Tani, A., S. Nozoe, M. Aoki and C.N. Hewitt 2002 Monoterpene fluxes measured above a Japanese red pine forest at Oshiba plateau, Japan. Atmos. Environ., 36: 3391-3402

Tittarelli, A., A. Borgini, M. Bertoldi, E. D. Saeger, A. Ruprecht, R. Stefanoni, G. Tagliabue, P. Contiero and P. Crosignani 2008 Estimation of particle mass concentration in ambient air using a particle counter. Atmos. Environ., 42: 8543-8548

Trapp, D., K.M. Cooke, H. Fischer, B. Bonsang, R.U. Zitzelsberger, R. Seuwen, C. Schiller, T. Zenker, U. Parchatka, T. V. Nunes and C.A. Pio 2001 Isoprene and its degradation products methyl vinyl ketone, methacrolein, and formaldehyde in a 
eucalyptus. Chemosphere., 3: 295-307

Ulrich, R. S., R. F. Simons, B. D. Losito, E. Fiorito, M. A. Miles and M. Zelson 1991 Stress recovery during exposure to natural and urban environments. J. Environ. Psychol., 11(3): 201230

Wang, S. Y., W. C. Lai, F. H. Chu, C. T. Lin, S. Y. Shen and S. T. Chang 2006 Essential oil from the leaves of cryptomeria japonica acts as a silverfish (Lepisma saccharina) repellent and insecticide. J. Wood. Sci., 52: 522-526

Wang, W., N. Li, M. Luo, Y. Zu and Thomas E. 2012 Antibacterial activity and anticancer activity of Rosmarinus officinalis L. essential oil compared to that of its main components. Molecules., 17: 2704-2713

WHO 2005 Air quality guidelines for particulate matter. Ozone, nitrogen dioxide and sulfur dioxide: Global Update 2005. pp. $1-22$

WHO 2014 Ambient(outdoor) air quality and health. Fact Sheet, 313

Wrench, A., R. Garrett and S. King 2013 Guessing where the goal posts are: Managing health and well-being during the transition to university studies. J. Youth Stud., 16(6): 730-746

Yang, Z., N. Wu, Y. Zu and Y. Fu 2011 Comparative anti-infectious bronchitis virus (IBV) activity of (-)-pinene: Effect on nucleocapsid (N) protein. Molecules., 16: 1044-1054

Yatagai, M., M. Ohira, T. Ohira and S. Nagai 1995 Seasonal variations of terpene emission from trees and influence of temperature, light, and contact stimulation on terpene emission. Chemosphere., 30(6): 1137-1149 